\title{
Wybór Biskupa Rzymskiego w perspektywie jedności Kościoła
}

Starodawna formuła św. Ambrożego w lakonicznych słowach ujmuje treść doktryny o Biskupie Rzymu: „ubi Petrus, ibi Ecclesia, ibi Deus”, czyli „gdzie jest Piotr, tam jest Kościół, tam też jest Bóg”. „Biskup Rzymu, jako Następca Piotra, jest trwałym i widzialnym źródłem i fundamentem jedności zarówno Kolegium Biskupów, jak i wszystkich wiernych” . „Gdyby w Chrystusowym Kościele zabrakło Piotrowego najwyższego urzędu pasterskiego z władzą skuteczną i rozstrzygającą, to znikłaby jedność, o której przywrócenie próżno byłoby się starać, trzymając się zasad wprowadzonych w miejsce jedynie prawdziwej normy ustanowionej przez Chrystusa. Słusznie bowiem powiada święty Hieronim: "Tyle byłoby w Kościele sekt, ilu kapłanów»"2.

W niniejszym przedłożeniu zostaną uwypuklone te elementy procedury wyboru papieża, które uwydatniają jedność wspólnoty wierzących - zarówno w znaczeniu udziału całego Kościoła w powołaniu Biskupa Rzymu, jak też w sensie szczególnego umocnienia papieża poprzez wybór do pełnienia posługi jedności powierzonej mu w Chrystusowym Kościele. Te elementy to: powierzenie wyboru papieża kardynałom Świętego Kościoła Rzymskiego, większość

I LG 23.

2 Paweł VI, Enc. Ecclesiam suam o drogach, którymi Kościół katolicki powinien kroczyć w dobie obecnej przy pełnieniu swojej misji, 6 VIII 1964, AAS, 1964, vol. 56, s. 656. 
głosów wymagana do wyboru Biskupa Rzymskiego oraz duchowy wymiar konklawe i wezwanie wszystkich wiernych do uczestnictwa tym szczególnym akcie.

\section{Elektorzy Biskupa Rzymskiego}

Po tym, gdy w pierwszym tysiącleciu chrześcijaństwa Biskup Rzymu był powoływany przez duchowieństwo i lud rzymski (do IV w.), a począwszy od Konstantyna Wielkiego wyznaczany przy udziale chrześcijańskich cesarzy i wpływie możnych rodów, od 1059 roku prawo wyboru papieża przysługuje wyłącznie kardynałom - początkowo kardynałom biskupom ${ }^{3}$, a od 1179 roku wszystkim członkom Kolegium Kardynalskiego ${ }^{4}$. Zastrzeżenie elekcji papieża dla Kolegium Kardynalskiego podyktowane było pragnieniem, by wybór dokonał się w środowisku eklezjalnym, w sposób wolny od zewnętrznych ingerencji świeckich władców i wpływowych możnych rodów, co nierzadko skutkowało wyborami antypapieży i podziałami w Kościele. To właśnie chęć zachowania niezależności Kościoła - libertas Ecclesiae - w wyborze swego Najwyższego Pasterza, zwłaszcza gdy weźmie się pod uwagę historyczny kontekst wyboru na Stolicę Piotrową samego Mikołaja II ${ }^{5}$, legła u podstaw jego przełomowej decyzji. Przełomem było zarówno ustalenie trwałych reguł, które odtąd miały rządzić wyborem Biskupa Rzymskiego, jak też powierzenie odpowiedzialności za elekcję papieża nielicznym, precyzyjnie wskazanym i wzbudzającym szacunek członkom duchowieństwa rzymskiego, tak by uniemożliwić dokonanie tego wyboru innym. I chociaż na utwierdzenie się nowych zasad trzeba było czekać jeszcze długo - trzeba było jeszcze przeżyć w Kościele wielką schizmę zachodnią, a ostatni w (dotychczasowej) historii antypapież $^{6}$ (Feliks V) pojawił się w XV wieku - to jednak decyzja Mikołaja II, przynajmniej de iure uniezależniająca wybór Biskupa Rzymu od władzy świeckiej i określająca precyzyjnie kolegium elektorskie, jest uznawana

3 Por. Mikołaj II, Bulla In nomine Domini, 1059 r., D. 23, c. 1.

4 Por. Aleksander III, Licet de vitanda, 1179 r., X 1, 6, 6 De electione.

5 Został on wybrany przez pięciu kardynałów biskupów zebranych poza Rzymem, bez udziału duchowieństwa i ludu rzymskiego. Elekcję Mikołaja II poprzedził jednak wybór antypapieża, uzurpatora, Benedykta X. Zob. m.in. A. M. Piazzoni, Historia wyboru papieży, Kraków 2004, s. 149.

6 Zob. J. Warmiński, H. Wojtyska, Antypapież, [w:] Encyklopedia katolicka, t. 1, Lublin 1989, kol. 727-728. 
za przełomowy moment w historii wyboru papieży ${ }^{7}$. Doniosłość tej decyzji polegała zwłaszcza na określeniu stałych reguł, wobec ich braku w pierwszym tysiącleciu, a także wobec praktyki wyborczej, tak skrajnie odmiennej od tej, którą znamy dziś w dobie demokracji ${ }^{8}$. Mimo to kolejne elekcje papieży wskazują, że dekret z roku 1059 nie był przestrzegany - w dalszym ciągu rościli sobie prawo do interwencji (przynajmniej w formie potwierdzenia legalności aktu wyboru) cesarze; niekiedy kardynałowie biskupi dokonywali wyboru w innych niż Rzym miejscowościach, aby uniknąć przewidywanych zadrażnień z duchowieństwem i ludem rzymskim. Jednak mimo iż rzadko elekcje odbywały się jednomyślnie i bez trudności, sama zasada, iż wybór papieża ma być dokonany przez kardynałów biskupów, została zachowana. Po kolejnym powołaniu antypapieża w roku 1159, dla uniknięcia na przyszłość waśni i sporów, papież Aleksander III w 1179 roku podczas Soboru Laterańskiego III w konstytucji o znamiennym tytule Licet de vitanda discordia określił, iż wszyscy kardynałowie, już bez różnicy stopnia, mają stanowić wyłączne gremium elekcyjne Biskupa Rzymu, a jeśli osiągnięcie jednomyślności kardynałów będzie niemożliwe, papieżem będzie ten, kogo wybrało dwie trzecie elektorów. W ten sposób w roku 1179 została sfinalizowana reforma, której początkiem było postanowienie Mikołaja II sprzed 120 lat, zaś grono kardynałów aż do dzisiejszych czasów niezmiennie stanowi gremium wyborcze papieża.

7 Zgodnie z bullą In nomine Domini wybór był rozłożony na trzy etapy. Najpierw kardynałowie biskupi winni przeprowadzić konsultacje i dokonać wyboru nowego papieża, którego w dalszej kolejności mieli zatwierdzić pozostali kardynałowie, a następnie pozostałe duchowieństwo i lud Rzymu. Jednak decydującym aktem był wybór dokonany przez kardynałów biskupów. W razie trudności, które mogłyby zagrozić wolności wyborów, kardynałowie mogli zebrać się poza Rzymem (tak właśnie wybrany został sam Mikołaj II), a gdziekolwiek by się nie osiedlili wraz z wybranym papieżem, tam jest Kościół Rzymski. Znamienną nowością było również określenie momentu uzyskania przez elekta władzy papieskiej: dokonywało się to z chwilą przyjęcia wyboru, niezależnie od objęcia stolicy rzymskiej i intronizacji, tak więc wybór nie mógł już być zablokowany, zwłaszcza przez władzę świecką. Co ciekawe, istniała także sfałszowana wersja bulli Mikołaja II, w której cesarzowi gwarantowano udział w wyborze papieża. Zob. A. M. Piazzoni, Historia..., dz. cyt., s. $151-153$.

8 Wybór papieża „przez duchowieństwo i przez lud” nie dokonywał się w drodze formalnego głosowania, ale miał raczej formę aklamacji „wiecowej”, bez ścisłego liczenia głosów. Zob. A. Petrani, Zasada większości w prawie kanonicznym, Lublin 1947, s. 8-13, 39. 
Uprawnienie do wyboru papieża należy do fundamentalnych prerogatyw kardynałów. Do tego stopnia, że prawo wyboru papieża wchodzi w skład kodeksowej definicji Kolegium Kardynalskiego zawartej w kan. 349: „Kardynałowie Świętego Rzymskiego Kościoła tworzą szczególne Kolegium, któremu przysługuje prawo wyboru Biskupa Rzymskiego (...)”. Dopiero w dalszych słowach tego przepisu stwierdza się, iż kardynałowie wspierają papieża w sprawowaniu przezeń funkcji pasterza Kościoła powszechnego, czy to kolegialnie, czy to indywidualnie. Jednak to prawo do wyboru papieża wysuwa się na pierwszy plan i jawi się jako najważniejsze spośród uprawnień kardynałów. Żaden z kardynałów elektorów nie może być z jakiegokolwiek powodu ani pod żadnym pretekstem odsunięty od uczestnictwa w konklawe?.

$\mathrm{Z}$ tej właśnie racji formułowano poważne zastrzeżenia w stosunku do motu proprio Pawła VI Ingravescentem aetatem z 21 listopada 1970 roku $^{10}$, w którym uprawnienie to zostało odebrane kardynałom, którzy ukończyli osiemdziesiąty rok życia. Ta decyzja, która sprawiła, że kolegium wyborcze papieża nie jest już tożsame z Kolegium Kardynalskim, budziła wątpliwości, a nawet krytyczne oceny, zwłaszcza z uwagi na to, że stanowiła przykład wyjątkowego działania prawa wstecz, pozbawiając uprawnień nabytych przez kardynałów kreowanych przed wejściem w życie motu proprio ${ }^{11}$. Mimo tych uwag Jan Paweł II podtrzymał decyzję Pawła VI odbierającą osiemdziesięcioletnim (i starszym) kardynałom prawo czynnego głosu na konklawe ${ }^{12}$. Swoją

9 Zob. Jan Paweł II, Konst. apost. Universi Dominici gregis o wakacie Stolicy Apostolskiej i wyborze Biskupa Rzymskiego, [dalej: UDG], 22 II 1996, AAS, 1996, vol. 88, s. 305-343, nr 35. Jak się wydaje, bezprawne niedopuszczenie kardynała elektora do udziału w konklawe skutkowałoby nieważnością wyboru. Zob. UDG 76.

ro Zob. AAS, 1970, vol. 62, s. 810-813. Tłumaczenie polskie: PPK, t. 3, z. 1, s. 9-15.

II Zob. kan. 4 i 9 KPK z 1983. Jeden z autorów nie powstrzymywał nawet swego zdziwienia tym, że prawo wyborcze papieża zezwala na udział w konklawe kardynałom, którzy znajdowaliby się w najcięższych karach kościelnych, a wyklucza zeń tych, których „jedyną winą jest to, że mają więcej niż osiemdziesiąt lat" (J. B. d'Onorio, Le Pape et le gouvernement de l'Église, Paris 1992, s. 427).

I2 Zob. UDG 33. Wartą odnotowania zmianą jest natomiast to, że granicę 80 lat dziś liczy się w stosunku do daty śmierci lub rezygnacji papieża, a nie - jak w poprzednim ustawodawstwie - w stosunku do dnia rozpoczęcia konklawe. Ponieważ Kolegium Kardynalskie cieszy się pewną ograniczoną swobodą w ustaleniu dnia początku konklawe (od 15 do 20 dnia po śmierci papieża), nowy przepis, stanowiący obiektywne kryterium, nie pozwala na wytoczenie zarzutu, że data rozpoczęcia konklawe mogłaby być wyznaczona z uwagi 
decyzję papież uzasadnił pragnieniem „nieobarczania tak czcigodnego wieku dodatkowym ciężarem". Przepis ten zmierza do tego, by gremium wyborców papieża składało się z osób, które będą potrafiły jak najlepiej zrozumieć, jakie są aktualne potrzeby Kościoła ${ }^{13}$.

Podtrzymana została sama - już prawie dziesięciowiekowa - zasada, że to wyłącznie kardynałowie cieszą się prawem wyboru papieża. Podkreślenie tego, co mogłoby wydawać się oczywiste, wcale nie jest zbyteczne, gdyż w nie tak odległej przeszłości pojawiały się i nadal pojawiają propozycje powierzenia wyboru papieża gremium składającemu się z innych osób, niż tylko samych kardynałów. Propozycje takie były wysuwane podczas Soboru Watykańskiego $\mathrm{II}^{14}$, a także później, w latach siedemdziesiątych ubiegłego wieku, podczas prac nad Lex Ecclesiae Fundamentalis. Postulowano m.in. utworzenie do tego celu organu kolegialnego, składającego się z biskupów wybranych przez poszczególne Konferencje Episkopatu, na zasadzie reprezentacji ${ }^{15}$. Zgłaszano również sugestie, by wyboru papieża dokonywali przewodniczący Konferencji Episkopatu, albo by funkcja kardynałów była pełniona czasowo. Pojawiały się również śmiałe, ale odwołujące się do praktyki pierwszych wieków Kościoła, propozycje dopuszczenia do wyboru Biskupa Rzymskiego osób świeckich ${ }^{16}$. Sam Paweł VI w 1973 roku ujawnił, iż rozważa rozszerzenie grona wyborców papieża o biskupów, patriarchów Kościołów wschodnich oraz członków Rady Sekretariatu Synodu Biskupów, co lepiej odpowiadałoby wymaganiom czasów ${ }^{17}$. Innymi, raz po raz powra-

na osiemdziesiąte urodziny któregoś z kardynałów, którego chciano by dopuścić lub wyłączyć z wyborów papieża.

r3 Zob. M. Mosconi, L'elezione del Romano Pontefice come espressione del suo ufficio di "perpetuo e visibile principio e fondamento dell'unità sia del Vescovi sia della moltitudine dei fedeli» (LG 23), „Quaderni di Diritto Ecclesiale”, 2009, vol. 22, s. 235.

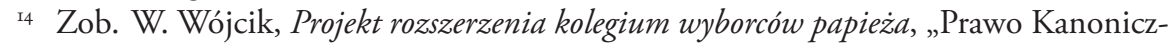
ne”, R. 28, 1975, nr 1-2, s. 26-27.

I5 Zob. P. Lombardía, J. Hervada, J. A. Souto, Sugerencias para la revisión del proyecto, [w:] El proyecto de Ley Fundamental de la Iglesia. Texto y análisis crítico, Pamplona 1971, s. 223, nr 26.

I6 Zob. G. May, Das Papstwahlrecht in seiner jüngsten Entwicklung. Bemerkungen zu der Apostolischen Konstitution „Romano Pontifici Eligendo", [w:] Ex aequo et bono. Wilibald M. Plöchl zum 70. Geburtstag, red. P. Leisching, F. Pototsching, R. Potz, Innsbruck 1977, s. 238-239.

${ }_{17}$ Zob. W. Wójcik, Projekt rozszerzenia..., dz. cyt., s. 28; G. P. Milano, Un progetto di Paolo VI per la riforma del Conclave, [w:] Paolo VI e la collegialità episcopale. Colloquio internazionale di studio. Brescia 25-26-27 settembre 1992, Brescia 1995, s. 372. 
cającymi pomysłami, są propozycje włączenia do Kolegium Kardynalskiego osób świeckich: „Zarządzanie Kościołem nie powinno być zarezerwowane dla starszych wiekiem mężczyzn - należy je powierzyć także innym, w tym małżonkom i ludziom młodym" 18 .

Jakie znaczenie dla jedności Kościoła - bo taki jest temat niniejszego przedłożenia - ma fakt zarezerwowania wyboru Biskupa Rzymskiego dla kardynałów?

Przede wszystkim nie jest pozbawione słuszności odwołanie się do tych samych racji, które towarzyszyły papieżom Mikołajowi II i Aleksandrowi III, gdy w wiekach XI i XII zastrzegali wybór papieża dla kardynałów, a tym samym przynajmniej w zamierzeniach uwalniali elekcję od zewnętrznych wpływów władzy świeckiej. Wprawdzie nie wykluczyło to w sposób absolutny możliwości niepożądanych ingerencji w powołanie Biskupów Rzymskich - ostatnie skuteczne weto $\mathrm{w}$ imieniu cesarza austriackiego zostało wniesione, iure et privilegio antiquo przez kard. Jana Puzynę na konklawe w 1903 roku $^{19}$ - ale umocniło jedność Kościoła. Także w tym sensie, że przez ustanowienie uniwersalnych reguł wyboru papieża (co jeszcze później zostało sformalizowane wraz z narodzeniem się instytucji konklawe) wybór mógł dokonywać się w sposób uregulowany, nie zaś w sprzyjającej waśniom i podziałom atmosferze wiecowej. Choć nowe reguły nie zagwarantowały całkowicie, by wybór papieża odbywał się bez sporów, znamienne jest, że po roku 1179 nastąpił stosunkowo długi okres bez antypapieży, w którym papiestwo przeżywało swój „złoty wiek” ${ }^{20}$. Powierzenie wyboru papieża kardynałom i dzisiaj, mimo

I8 J. Borkowicz, I ty zostaniesz kardynatem, "Tygodnik Powszechny”, 27 III 2011, nr 13, s. 19. Autor przytacza apel wydawanego przez jezuitów w USA katolickiego tygodnika „America”.

I9 Biskup krakowski w imieniu cesarza z przyczyn politycznych wniósł weto wykluczające (tzw. ekskluzywę) wobec kard. Rampolli wymienianego jako faworyt na tron papieski. Kardynałowie zebrani na konklawe zaprotestowali przeciwko ingerencji cesarskiej, ale ostatecznie kard. Rampolla nie został wybrany. Konklawe to wyłoniło papieża Piusa X, który niespełna pół roku po swoim wyborze w konst. apost. Commissum nobis z 20 I 1904 pod groźbą ekskomuniki latae sententiae zakazał wnoszenia weta podczas konklawe. Tekst tej konstytucji był dołączany do pierwszych wydań kodeksu z 1917 roku, a sam zakaz znalazł się we wszystkich późniejszych konstytucjach apostolskich regulujących konklawe (zob. UDG 80). Na temat weta zgłoszonego przez kard. Puzynę zob. m.in. J. Urban, Relacja kard. Jana Puzyny o konklawe 1903 r. i o jego stynnym weto, „Folia Historica Cracoviensia”, R. 8, 2002, s. 273-276.

20 Zob. A. M. Piazzoni, Historia..., dz. cyt., s. 169-170. 
doświadczeń z wieków minionych, stanowi swoistą gwarancję tego, że wybór dokona się w gruncie rzeczy spokojnie, bez niszczących zatargów, wstrząsania Kościołem konfliktami i zagrożenia rozłamem. Przyczynia się do tego, rzecz jasna, sama instytucja konklawe, której prawna regulacja, a więc normy proceduralne, dyscyplinarne, karne i liturgiczne tworzą całościowy system zmierzający do zagwarantowania elektorom swobody wyboru, a zwłaszcza wolności od wpływów zewnętrznych (politycznych i medialnych) oraz zapewnienia tego, by wybór papieża dokonał się w atmosferze religijnego skupienia.

Zgodnie z kan. 351 \$ 1 KPK Biskup Rzymski mianuje (kreuje) kardynałów swobodnie i niezależnie, wybierając do tej godności tych, którzy w jego ocenie jak najlepiej będą służyć Kościołowi ${ }^{21}$. W nominacji nie jest związany tym, że dany biskup jest biskupem miejsca, które tradycyjnie uchodzi za „stolicę kardynalską”. Nie istnieją już także historyczne przywileje rekomendowania kandydatów na kardynałów, jakimi w przeszłości cieszyły się głowy państw katolickich $^{22}$. Nie bez znaczenia są natomiast wysokie kwalifikacje i poziom ludzki, religijny, duchowy oraz intelektualny tych, których papież powołuje do Kolegium Kardynalskiego. Papież ustanawia kardynałów, wybierając ich spośród duchownych wybitnie odznaczających się „szczególną nauką, obyczajami, pobożnością i roztropnością w załatwianiu spraw" ${ }^{23}$. Przymioty te mają gwarantować, że kardynałowie będą pełnili swoje zadania kompetentnie, a wyboru następcy św. Piotra dokonają z najwyższą odpowiedzialnością i troską o dobro Kościoła: „mając przed oczami tylko Boga i wyłącznie «zbawienie dusz, które zawsze winno być w Kościele najwyższym prawem»"24, co przecież ze wszech miar przyczynia się do zachowania jedności Kościoła. Warto też w tym kontekście przywołać formułę przysięgi wypowiadanej przez poszczególnych elektorów za każdym razem, gdy składają do urny wypełnioną kartę

${ }^{21}$ Nie bez racji mówi się, że papież „mianuje” swego następcę. Powołując kandydatów do Kolegium Kardynalskiego, sam kształtuje bowiem gremium, które będzie wybierać jego następcę. Tym samym ma w jakimś stopniu i pośrednio wpływ na wynik przyszłego konklawe.

${ }_{22}$ Zob. J. Krukowski, Komentarz do kan. 351, [w:] Komentarz do Kodeksu Prawa Kanonicznego, t. 2/1: Księga II. Lud Boży. Część I. Wierni chrześcijanie. Część II. Ustrój hierarchiczny Kościoła, red. J. Krukowski, Poznań 2005, s. 188.

23 Kan. $351 \$ 1$.

${ }^{24}$ UDG, wstęp. Odpowiedzialność i powinność kierowania się elektorów wyłącznie dobrem Kościoła jest przedmiotem ascetycznych rozważań i modlitw elektorów podczas konklawe. 
wyborczą: „Powołuję na świadka Chrystusa Pana, który mnie osądzi, że mój głos jest dany na tego, który - według woli Bożej - powinien być, moim zdaniem, wybrany" ${ }^{25}$. Nie można zapominać, że wybór dokonany na konklawe nie jest wyborem o charakterze politycznym, ale w najwyższym stopniu religijnym.

Korzystne jest, że kolegium wyborcze papieża musi być stałe (a nie powoływane w czasie wakatu Stolicy Apostolskiej) i niezbyt liczne, aby można je było bez zwłoki zebrać. Przy gremium liczącym zbyt wielu członków zmniejszają się zaangażowanie i osobista odpowiedzialność za podejmowane decyzje, a wymiana poglądów między uczestnikami wyborów jest bardziej ograniczona. Oczywistą jest rzeczą, że wybór powierzony gronu elektorów, którzy należą do grona najwybitniejszych ludzi Kościoła i tworzą gremium o liczbie nieprzekraczającej stu dwudziestu członków ${ }^{26}$, z natury rzeczy może być przeprowadzony sprawniej, korzystniej i bez zagrożenia działaniami o charakterze populistycznym, niż elekcja dokonana „przez duchowieństwo i lud”, ale także przez dużo liczniejsze grono wiernych, które miałoby stanowić reprezentację Kościoła powszechnego. Czy można odmawiać tej reprezentatywności Kolegium Kardynalskiemu? ${ }^{27} \mathrm{Z}$ pewnością nie jest ono reprezentatywne w takiej mierze, w jakiej jest nią np. zgromadzenie generalne zwyczajne Synodu Biskupów, którego członkowie w części wyłaniani są przez poszczególne Konferencje Episkopatu, proporcjonalnie do ich liczebności, zgodnie z przepisami specjalnego prawa $^{28}$. Trzeba jednak mieć na uwadze, że zgromadzeni na konklawe kardy-

25 UDG 66.

${ }_{26}$ Taką liczbę ustala UDG 33. Jej przekroczenie - co zdarzyło się za pontyfikatu Jana Pawła II - nie powoduje jednak reperkusji w postaci nieważności wyboru. Nie może też być powodem niedopuszczenia któregoś z kardynałów do konklawe.

${ }_{27}$ Pojawia się nawet pogląd, że zasady wyboru papieża w pierwszych wiekach, jako mniej sformalizowane, były tym samym „bardziej demokratyczne”. Zob. K. Krzysztofek, Pierwsze sposoby elekcji papieży, [w:] Vetera Novis Augere. Studia i prace dedykowane Profesorowi Wactawowi Uruszczakowi, red. S. Grodziski, D. Malec, A. Karabowicz, M. Stus, t. 1, Kraków 2010, s. 529.

${ }_{28}$ Zob. kan. $346 \$ 1$. Prawem specjalnym Synodu jest Regulamin Synodu Biskupów (Ordo Synodi Episcoporum) z dnia 29 IX 2006, AAS, 2007, vol. 98, s. 755-779. Zgodnie z art. 6 Regulaminu Konferencja Episkopatu licząca do 25 członków wybiera jednego reprezentanta, Konferencja licząca 26-50 członków wybiera dwóch delegatów, Konferencja licząca 51-100 członków posyła trzech przedstawicieli, a konferencja licząca ponad 100 członków wybiera czterech reprezentantów. 
nałowie nie wyłaniają reprezentanta Kościoła powszechnego, ale ich zadaniem jest wybór Biskupa Rzymu, a ten wybór, mając na uwadze hierarchiczny ustrój Kościoła, wcale nie musi dokonywać się demokratycznie.

Konstytucja apostolska Universi Dominici gregis zawiera bardzo celne uzasadnienie uprawnienia grona kardynałów do wyboru Biskupa Rzymu. Warto przytoczyć ten fragment w całości „Wyrażają oni, jakby w przedziwnej syntezie, dwa aspekty, które charakteryzują postać i urząd Biskupa Rzymskiego: jest on Biskupem Rzymskim, ponieważ jest utożsamiony z osobą Biskupa Kościoła, który jest w Rzymie, a więc pozostaje w ścisłej relacji z duchowieństwem tego Miasta, reprezentowanym przez Kardynałów z tytułami prezbiterów i diakonów Rzymu oraz przez Kardynałów biskupów kościołów podmiejskich; jest Biskupem Kościoła powszechnego, ponieważ jest powołany do zastępowania w sposób widzialny Pasterza niewidzialnego, który prowadzi całą owczarnię na pastwiska życia wiecznego. Powszechność Kościoła jest więc dobrze przedstawiona w samym składzie Kolegium Kardynalskiego, obejmującym purpuratów ze wszystkich kontynentów”.

Ta podwójna funkcja Kolegium Kardynalskiego ma podczas wyboru papieża niezwykle istotne eklezjalne znaczenie. Kardynałowie Świętego Kościoła Rzymskiego - warto zaakcentować tę oficjalną nomenklaturę - swój ścisły związek z Rzymem zachowują przez nadany im przez papieża kościół tytularny, diakonię lub diecezję podmiejską (suburbikarna) ${ }^{29}$. W ten sposób kardynałowie $^{30}$ należą do duchowieństwa rzymskiego ${ }^{31}$ (przynajmniej w znaczeniu

29 Zob. kan. $350 \$ 1$ i 2 oraz kan. $357 \$ 1$. Uprawnienia kardynałów w powierzonych im diecezjach lub kościołach są wyłącznie honorowe.

30 Z wyjątkiem patriarchów Kościołów Wschodnich, którym nie zostaje nadany żaden tytuł w Rzymie, i o których wyraźnie postanawia się, że „nie należą do duchowieństwa rzymskiego". Zob. Paweł VI, Motu proprio Ad purpuratorum Patrum, 11 II 1965, AAS, 1965, vol. 57, s. 295-296. Racją takiego wyłączenia patriarchów wschodnich jest szacunek dla ich autonomii. Z użytego przez papieża sformułowania można jednak, a sensu contrario, wnioskować, że pozostali kardynałowie „należą” do kleru Wiecznego Miasta.

${ }^{31}$ Zgodnie z przepisem kan. 356, do zamieszkania w Rzymie są zobowiązani tylko ci kardynałowie, którzy nie są biskupami diecezjalnymi i sprawują urząd w Kurii Rzymskiej. Pozostali kardynałowie powinni przybyć do Rzymu ilekroć są wezwani przez papieża. W myśl najnowszej ustawy o obywatelstwie, zamieszkaniu i wstępie do Państwa Miasta Watykańskiego, kardynałowie rezydujący w Rzymie (także w Watykanie) są obywatelami Państwa Miasta Watykan i tracą to obywatelstwo wraz z utratą zamieszkania w Rzymie. Zob. Benedetto XVI, Legge sulla cittadinanza, la residenza e l'accesso, 22 II 2011, „Communicationes”, R. 43, 2011, nr 1, s. 24-25, 
moralnym), i jako kwalifikowani wyborcy Biskupa Rzymskiego kontynuują dawną tradycję elekcji papieża przez duchowieństwo Wiecznego Miasta. Przypomniał o tym Paweł VI we wstępie do konstytucji apostolskiej Romano Pontifici eligendo- z 1 października 1975 roku $^{32}$ : „Zgodnie ze starożytną tradycją, wybór papieża należy do Kościoła Rzymskiego, czyli do reprezentującego go Kolegium Kardynalskiego". Mimo iż twierdzenie o reprezentowaniu kleru rzymskiego przez kardynałów nie jest dziś przez wszystkich komentatorów przyjmowane bez zastrzeżen ${ }^{33}$ i jest bardziej formalne niż rzeczywiste, podtrzymanie go jawi się jako konieczne, jeśli pamiętać o fundamentalnym eklezjologicznym założeniu, iż papież jest Głową Kolegium Biskupów i ośrodkiem jedności Kościoła wyłącznie jako Biskup Rzymu, następca św. Piotra. Kardynałowie wybierają wszak nie swego rodzaju reprezentanta biskupów świata, ale Biskupa Rzymu, który wraz z przyjęciem wyboru jako Biskup Rzymu staje się Głową Kościoła Powszechnego ${ }^{34}$.

art. 1, ust. 1a oraz art. 3, ust. 1a. Natomiast wszyscy kardynałowie cieszą się wolnym wstępem na teren Watykanu, bez potrzeby uzyskiwania dodatkowych zezwoleń (art. 11, p. a).

$3^{2}$ Konst. apost. Romano Pontifici eligendo, [dalej: RPE], 1 X 1975, AAS, 1975, vol. 67, s. 609-645. Tłumaczenie polskie: PPK, t. 8, zesz. 1, s. 7-76. Pawłowi VI bardzo zależało na podkreśleniu ścisłych związków Kolegium Kardynalskiego z Rzymem. Wyrazem tego był cykl artykułów opublikowanych w watykańskim dzienniku „L'Osservatore Romano” zaraz po ogłoszeniu regulacji wyboru papieża. Było to spowodowane koniecznością uwypuklenia ustrojowego związku prymatu papieskiego z rzymską stolicą. Zob. P. Majer, „Universi Dominici gregis”. La nueva normativa sobre la elección del Romano Pontifice, "Ius Canonicum”, R. 36, 1996, nr 72, s. 673-680, zwłaszcza przyp. 29.

$33 \mathrm{~Np}$. J. Miñambres, Il governo della Chiesa durante la vacanza della Sede Romana e l'elezione del Romano Pontefice, „Ius Ecclesiae”, R. 8, 1996, s. 722 wyraża opinię, że kardynałowie nawet w sensie moralnym nie mogą być uznawani za reprezentację duchowieństwa Rzymu. Inny autor uważa, że przynależność kardynałów do duchowieństwa rzymskiego stanowi jedynie fictio iuris. Zob. M. Graulich, Die Vakanz des Apostolischen Stubls und die Wahl des Bischofs von Rom - Zwei Rechtsinstitute in der Entwicklung, „Archiv für Katholisches Kirchenrechts", R. 174, 2005, s. 89.

34 Tak też brzmi pełny tytuł nr 35 konst. apost. Jana Pawła II Universi Dominici gregis o wakacie Stolicy Apostolskiej i wyborze Biskupa Rzymskiego. Stawiano zarzut, że kartka wyborcza używana podczas konklawe zawiera napis: „Eligo in Summum Pontificem...”, a nie „in Romanum Pontificem” (zob. UDG 65). Podobnie formuła zapytania o przyjęcie przez elekta wyboru brzmi: „Acceptasne electionem de te canonice factam in Summum Pontificem?” (UDG 87). Zob. W. Wójcik, Nowe prawo o wyborze papieża, „Prawo Kanoniczne”, R. 20, 1977, nr 3-4, s. 97-98. Niezależnie od tego, wybrany (jeśli jest już biskupem) wraz z przyjęciem wyboru „staje się natychmiast Biskupem Kościoła Rzymskiego, prawdziwym Papieżem 
Z drugiej strony, choć w obowiązującym kan. $351 \$ 1$ nie ma już wyraźnej klauzuli dawnego kan. $232 \$ 2$ KPK z 1917, iż papież powołuje kardynałów ex toto terrarum orbe, stosowne umiędzynarodowienie Kolegium Kardynalskiego jest przedmiotem stałej troski Ojca Świętego ${ }^{35}$. Ten proces stopniowej internacjonalizacji grona wyborców papieża powoduje jednak swego rodzaju przesunięcie akcentu w funkcji tegoż Kolegium - od bycia reprezentacją kleru rzymskiego w stronę reprezentowania biskupów rozsianych po całym świecie ${ }^{36}$. Sprawia to tak wzrost liczby członków Kolegium $\mathrm{w}$ ostatnich dziesięcioleciach ${ }^{37}$ oraz jego znaczące zróżnicowanie pod względem krajów pochodzenia poszczególnych kardynałów, jak również to, iż zasadniczo wszyscy kardynałowie powinni przyjąć święcenia biskupie ${ }^{38}$. Można zatem uznać, że Kolegium Kardynalskie, poza zadaniem reprezentowania duchowieństwa rzymskiego stanowi także wiarygodne odzwierciedlenie światowego episkopatu ${ }^{39}$. Oznaczałoby to jednak - podobnie jak przywoływane propozycje rozszerzenia kolegium wyborców papieża, ostatecznie odrzucone przez Pawła VI - wyjęcie elekcji papieża z orbity rzymskiej i wprowadzenie jej w sferę kolegialności biskupów ${ }^{40}$. Stąd tak ważne jest przypomnienie Jana

i Głową Kolegium Biskupiego”. Tu tytuł Biskupa Rzymu jest wymieniany jako pierwszy. Podobnie jak w kan. 331, w którym szyk zdania wyraźnie wskazuje na pierwszeństwo: „Biskup Kościoła Rzymskiego [...] jest Głową Kolegium Biskupów, Zastępcą Chrystusa i Pasterzem całego Kościoła tutaj na ziemi”.

3517 XI 2011 roku na 112 kardynałów elektorów, z Europy było 57 (w tym 12 Włochów, 5 Niemców, po 4 Francuzów, Hiszpanów i Polaków), z Ameryki Płn. 13, z Ameryki Łacińskiej 41, z Afryki 11, z Azji 9 i z Oceanii 1 (dane podaję, po zaktualizowaniu, za stroną www.vatican.va).

${ }^{6}$ Zob. J. I. Arrieta, Il sistema elettorale della cost. ap. „Universi Dominici gregis”, „Ius Ecclesiae”, R. 12, 2000, s. 143-144.

37 W 1586 roku papież Sykstus V w konstyt. apost. Postquam verus ille określił maksymalną liczbę kardynałów na 70. To ograniczenie zostało faktycznie zniesione przez Jana XXIII w 1958 roku. Paweł VI w przemówieniu wygłoszonym podczas konsystorza 5 III 1973 roku (AAS, 1973, vol. 65, s. 163) wyjaśnił, że zwiększenie liczebności Kolegium wynikało z eklezjologii Soboru Watykańskiego II, a jego celem było nadanie Kolegium Kardynalskiemu szczególnej reprezentatywności. Obecnie nie określa się maximum, choć pozostaje w mocy postanowienie UDG 33, iż liczba elektorów nie powinna przekraczać 120. Aktualnie (17 XI 2011) wszystkich kardynałów jest 193.

$3^{8}$ Zob. kan. $351 \S 1$.

39 Zob. J. I. Arrieta, Diritto dell'organizazione ecclesiastica, Milano 1997, s. 282.

$4 \circ$ Zob. tenże, Il sistema elettorale..., dz. cyt., s. 144. 
Pawła II o podwójnym aspekcie gremium wyborczego papieża, zwłaszcza zaś o tym, iż nie można tracić z oczu tej szczególnej cechy, jaką jest romanitas Kolegium Kardynalskiego.

Zastrzeżenie dla kardynałów prawa głosu czynnego w wyborze następcy św. Piotra zarówno z racji historycznych i założeń eklezjologicznych, jak i z powodów czysto funkcjonalnych stanowi zatem rozwiązanie optymalne i sprzyjające jedności Kościoła. Być może zbyt odważne byłoby stwierdzenie, iż ta praktyka nie zmieni się aż do końca świata, jak wyrażał się pod koniec XIX wieku autor cenionego traktatu o Kurii Rzymskiej ${ }^{41}$, ale nie wydaje się, by gremium wyborcze papieża $\mathrm{w}$ dającej się przewidzieć przyszłości miało ulec radykalnym zmianom.

\section{Większość głosów wymagana do wyboru papieża ${ }^{42}$}

Elementem konklawe, który wyraża i utwierdza jedność Kościoła, jest konieczność uzyskania większości kwalifikowanej dwóch trzecich głosów do ważnego wyboru następcy św. Piotra. Wymowa tego przepisu jest widoczna zwłaszcza w kontekście historycznym. Wymóg większości kwalifikowanej (w odróżnieniu od większości absolutnej, z reguły obowiązującej w wyborach kanonicznych, gdzie dla ważnego wyboru wystarcza uzyskanie ponad połowy głosów ${ }^{43}$ ), od ponad ośmiu wieków niezmiennie obecny w normach określających wybór papieża, został ustanowiony przez Aleksandra III we wspomnianej konstytucji Licet de vitanda discordia z 1179 roku. Papież pisał w niej: „Wydajemy zatem postanowienie, że jeżeli kardynałowie nie będą mogli osiągnąć pełnej jednomyślności co do ustanowienia papieża, ponieważ nieprzyjaciel człowieka nie przestaje wysiewać chwastu niezgody, i gdy dwie części osiągną zgodę, a trzecia część nie będzie chciała tego zaaprobować albo ośmieli się sama wybrać kogoś innego, wówczas za Biskupa Rzymskiego niech będzie uważany ten,

4I Zob. D. Bouix, Tractatus de Curia Romana, Parisiis 1880, s. 125.

${ }^{42}$ W tej części artykułu odwołuję się zasadniczo do dwóch własnych wcześniejszych opracowań: Większość głosów wymagana do wyboru papieża wedtug konstytucji apostolskiej Jana Pawła II „Universi Dominici gregis”, „Analecta Cracoviensia”, 1997, t. 29, s. 659-678; Nowelizacja prawa o wyborze papieża dokonana przez Benedykta XVI, „Annales Canonici”, R. 5, 2009, s. 179-195.

43 Zob. kan. 119, $1^{\circ}$. 
który został wybrany i zaakceptowany przez dwie części” ${ }^{44}$. Mniejszość, która obstawałaby przy własnym elekcie, miała wraz z nim podlegać ekskomunice.

Słowa papieża o niemożności dojścia do zgody nawiązują do praktyki wyborczej z pierwszych wieków chrześcijaństwa, kiedy to ideałem i zwyczajną formą wyborów w Kościele była elekcja jednogłośna, w której dopatrywano się natchnienia Ducha Świętego: to sam Bóg wybiera pasterzy Kościoła. Tak rozumiana spontaniczna jednomyślność wyborców wyrażała jedność Kościoła, będąc zarazem gwarancją, iż na urząd kościelny zostanie powołana osoba naprawdę tego godna. Dlatego też rozbieżność głosów bywała traktowana jako zjawisko niegodziwe i naganne. Chociaż w praktyce jednomyślność okazywała się czasem bardziej formalna niż rzeczywista, bo faktycznie pojawiały się głosy przeciwne, to jednak wybór jednogłośny zawsze uznawano za ideał, a oponentów przy pomocy perswazji i nacisków przekonywano do zaakceptowania woli większości wyborców.

Pamiątką i wyrazem takiej formy wyborów był wybór papieża przez aklamację (per acclamationem seu inspirationem), która polegała na spontanicznym, jednomyślnym opowiedzeniu się wszystkich elektorów za jedną kandydatura, bez formalności właściwych głosowaniom. Jeszcze po 1059 roku zostało w ten sposób wybranych sześciu papieży ${ }^{45}$. Aklamacja, obecna jeszcze w regulacji konklawe Pawła VI z roku $1975^{46}$, została zniesiona przez Jana Pawła II w konstytucji Universi Dominici gregis ${ }^{47}$.

$\mathrm{Z}$ czasem jednak rozumienie jednomyślności w wyborach kanonicznych uległo zmianie. Począwszy od IV/V wieku rozwijała się praktyka znana jako sanioritas. W myśl tej zasady, jeśli nie było możliwe osiąnnięcie jednomyślności, do ważności wyboru wystarczało zdobycie głosów określonej części kole-

${ }_{4}$ Przekład polski za: Dokumenty Soborów Powszechnych. Tekst grecki, taciński, polski, red. A. Baron, H. Pietras, t. 2 (869-1312), Kraków 2002, s. 168-169.

45 Zob. P. V. Aimone, Le modalità procedurali dell'elezione del vescovo romano nel secondo millennio, „Apollinaris”, R. 79, 2006, s. 592-619. Ostatnim z wybranych w ten sposób był Klemens VI (1342 r.).

${ }_{46}$ Zob. art. 63. PPK, t. 8, zesz. 1, s. 51-52. Warunkiem ważności wyborów w tej formie była jednomyślna, spontanicznie wyrażona, słowem lub na piśmie, przez wszystkich po kolei wyborców, bez uprzednich pertraktacji, proklamacja papieża po zamknięciu konklawe. Zob. też W. Wójcik, Aklamacja, [w:] Encyklopedia katolicka, t. 1, Lublin 1989, kol. 237-238.

47 Swą decyzję papież tłumaczył w preambule do konstytucji tym, iż forma ta jest nieadekwatna dla tak licznego i zróżnicowanego gremium wyborczego. 
gium wyborczego (np. kapituły), którą to część określano jako pars sanior (część zdrowsza). Aby osądzić, czy rzeczywiście ta część kolegium wyborczego, która stanowi większość, jest sanior, interweniowała władza zwierzchnia: papież, metropolita, biskupi sąsiednich Kościołów czy okoliczni opaci. Ponieważ przy wyborze na Stolicę Piotrową nie ma jednak kompetentnego przełożonego, który mógłby rozstrzygać konflikty i zatwierdzić wybór, Aleksander III wprowadził zasadę większości kwalifikowanej, która miała na przyszłość ratować Kościół przed bolesnymi skutkami wymarzonej, a tak trudno osiagalnej jednomyślności. Takie rozwiązanie stanowiło moment zwrotny w kanonicznej regulacji wyboru papieża. Było ono także, jak zauważa Petrani, wprowadzeniem do techniki wyborów większości kwalifikowanej, nieznanej w prawie rzymskim, a później przyjętej i ogólnie stosowanej także w systemach wyborczych państw nowożytnych ${ }^{48}$.

Wymóg większości kwalifikowanej w wyborach papieża miał na celu ustrzeżenie się na przyszłość przed niebezpieczeństwem wyłonienia przez gremium wyborcze dwóch (lub więcej) zwalczających się pretendentów do tiary, co zresztą rzeczywiście wydarzyło się bezpośrednio przed elekcją Aleksandra III. Bez wątpienia instytucja ta służyła zatem jedności Kościoła. Tę funkcję pełni także i dzisiaj, choć już w nieco innym sensie. Większość kwalifikowana, jako trudniejsza do osiągnięcia niż większość bezwzględna, i dlatego stosowana stosunkowo rzadko, zazwyczaj przy podejmowaniu decyzji o ważkim znaczeniu ${ }^{49}$, jest zatem instrumentem, który ma zapewnić, by decyzje szczególnie istotne cieszyły się poparciem znacznej większości decydujących. Wymóg ten obliguje bowiem pokaźną część gremium do opowiedzenia się

${ }^{4}$ Zob. A. Petrani, Geneza większości kwalifikowanej, „Roczniki Teologiczno-Kanoniczne”, R. 3, 1956, zesz. 1, s. 311-320.

49 Np. Konstytucja Rzeczypospolitej Polskiej wymaga w Sejmie większości kwalifikowanej dwóch trzecich głosów przy zmianie Konstytucji (art. 235 ust. 4), skróceniu kadencji Parlamentu (art. 98 ust. 3), zgody na ratyfikację umowy międzynarodowej przekazującej organizacji międzynarodowej lub organowi międzynarodowemu kompetencje organów władzy państwowej w niektórych sprawach (art. 90 ust. 2). Większości kwalifikowanej w Zgromadzeniu Narodowym wymaga się natomiast w celu uznania trwałej niezdolności Prezydenta RP do sprawowania urzędu ze względu na stan jego zdrowia (art. 131 ust. 2 p. 4) lub w celu postawienia Prezydenta RP w stan oskarżenia przed Trybunałem Stanu (art. 145 ust. 2). Kodeks prawa kanonicznego przewiduje konieczność uzyskania takiej większości kwalifikowanej przy uchwalaniu przez Konferencję Episkopatu dekretów ogólnych (kan. 455 \$ 2), a także przy postulacji kanonicznej (kan. $181 \$ 1$ ). 
za jedną propozycją, skłaniając do dyskusji, dialogu, zawiązywania sojuszów, tak iż ostateczny wynik głosowania - podjęcie decyzji lub wybór osoby - jest bardziej reprezentatywny aniżeli w przypadku większości zwykłej czy nawet absolutnej. Mniejsza też jest liczba osób, które muszą się podporządkować tak wypracowanej decyzji, mimo iż jej nie popierały.

W warunkach konklawe większość kwalifikowana stanowi swego rodzaju gwarancję co do kandydata, wzmacniając przekonanie, iż wybrany jest naprawdę najlepszym i najgodniejszym z możliwych i ciesząc się tak wysokim poparciem Kolegium Kardynalskiego - którego członkowie są przecież osobami wysoce kompetentnymi w sprawach Kościoła powszechnego - będzie jak najlepiej sprawował powierzone mu ministerium, ciesząc się przy tym na tyle silnym poparciem, by móc bez przeszkód kierować Kościołem, nie narażając się po wyborze na silną opozycję „wewnętrzną”. Nawet jeśli tego rodzaju argumentacja czysto „matematyczna” może wydawać się nie w pełni adekwatna do rzeczywistości eklezjalnej, nie można nie uwzględniać, iż znajduje ona w jakimś stopniu zastosowanie także i w stosunkach kościelnych. Oczywiście w uwarunkowaniach konklawe nie można pomijać duchowego wymiaru decyzji podejmowanych przez Kolegium Kardynalskie, a wysiłków podejmowanych przez wyborców papieża, zmierzających do osiągnięcia większości kwalifikowanej nie wolno interpretować wyłącznie w politycznym kluczu zwalczających się frakcji i zawiązywania taktycznych sojuszów ${ }^{50}$.

Osiagnięcie stosunkowo wysokiej większości w tak licznym i pod wieloma względami zróżnicowanym gremium, jakim jest dzisiaj Kolegium Kardynałów, może okazać się trudne i spowodować znaczne przedłużanie się konklawe $^{51}$. Czas jego trwania nie jest określony przepisami - winno ono trwać

50 Podczas konklawe nie wolno zawierać żadnych układów, które zobowiązywałyby do głosowania na określonych kandydatów lub odmówienia któremukolwiek z nich głosu (zob. UDG 81). Tego rodzaju zobowiązania należy traktować jako niebyłe i nieobowiązujące, a przekraczający ów zakaz zaciągają karę ekskomuniki latae sententiae. Nie wolno również żadnemu z kardynałów - także pod sankcją nieważności - podejmować tzw. kapitulacji wyborczych, czyli czynić przed wyborami ustępstw czy też podejmować za wspólną zgodą obietnic, zobowiązując się do wypełnienia ich w przypadku, gdyby któryś z zawierających tego rodzaju porozumienie został wyniesiony do godności papieskiej (zob. UDG 82).

${ }^{5}$ Tabelaryczne zestawienie czasu trwania poszczególnych konklawe od powstania tej instytucji podaje W. Jakubowski, O Roma felix. Geneza, specyfika i przeobrażenia instytucji politycznych Państwa Miasta Watykańskiego, Warszawa 2005, s. 267-270. Ostatni znacznie 
do dokonania skutecznego wyboru Biskupa Rzymu. Niemniej konstytucja apostolska Universi Dominici gregis przewiduje pewne instrumenty, które w razie impasu wyborczego mają pozwolić na przezwyciężenie i zażegnanie ewentualnych kryzysów wyborczych oraz doprowadzenie elekcji do końca. Te właśnie rozwiązania stały się w ostatnich latach przedmiotem interesującej dyskusji i nowelizacji ustawodawstwa o wyborze papieża.

Tradycją wyborów papieża było powtarzanie głosowań aż do skutku, tzn. aż do osiągnięcia większości kwalifikowanej przez jednego z kandydatów. Swobodna wymiana opinii między kardynałami elektorami, dni modlitewnego skupienia i medytacji są środkami przewidzianymi przez prawo ${ }^{52}$, zmierzającymi do tego, by wyborcy doszli do porozumienia. Lecz pomimo istnienia takich środków, nie można wykluczyć ewentualności zaistnienia trudnych sytuacji, w których wyborcy nie osiągną konsensu wymaganego dla wyboru papieża.

Jedną z nowości wprowadzonych przez Pawła VI było zastosowanie w procedurze wyboru papieża środków techniczno-prawnych wychodzących naprzeciw możliwym impasom. Konstytucja Romano Pontifici eligendo przewidywała możliwość skorzystania z systemu kompromisu ${ }^{53}$ albo, po serii ponad trzydziestu bezowocnych głosowań, obniżenie wymaganej większości kwalifikowanej do większości bezwzględnej głosów, lub też zawężenie grona kandydatów do dwóch, którzy w ostatnim głosowaniu otrzymali największą liczbę głosów $^{54}$. Na zastosowanie każdego z tych sposobów wymagana była jednomyślna zgoda całego kolegium elektorów Biskupa Rzymskiego.

Kiedy w 1975 roku promulgowano konstytucję Romano Pontifici eligendo, nowatorskie dopuszczenie w niej możliwości obniżenia uświęconego wielowiekową tradycją progu większości kwalifikowanej zostało uznane jako wyraz obaw Pawła VI, który - jak utrzymywali niektórzy - świadom rozdźwięków istniejących w Kolegium Kardynalskim, miał obawiać się nadmiernego przedłużania

przeciągający się wybór papieża miał miejsce przed wyborem Grzegorza XVI w 1831 roku. Konklawe trwało wówczas 50 dni, ale już czas trwania żadnego z następnych nie przekroczył 4 dni.

${ }^{52}$ Zob. UDG 74.

53 Kompromis - obecnie nie może być już stosowany podczas konklawe, ale znajduje zastosowanie przy innych wyborach kanonicznych (kan. 174-175) - polegał według RPE 64, na możliwości powierzenia wyboru papieża wyłonionym z grona kardynałów delegatom zwanym kompromisariuszami, w liczbie nieparzystej między 9 a 15 .

54 Zob. RPE 76. 
się przyszłego konklawe $e^{55}$. I chociaż przyszłość tych obaw nie potwierdziła ${ }^{56}$, Jan Paweł II wprowadził nowelizacje idące jeszcze dalej, co ponownie wywołało żywe zainteresowanie i dyskusję komentatorów. Podczas gdy konstytucja Pawła VI dla zastosowania nadzwyczajnej procedury wyborczej w przypadku nadmiernie przedłużającego się konklawe żądała jednomyślnej decyzji kolegium elektorów, prawo Jana Pawła II przewidywało, iż po jedenastu dniach bezskutecznych głosowann ${ }^{57}$ kardynałowie większością absolutną mogli zadecydować o przejściu do jednej z dwóch (po zniesieniu wyboru per compromissum) przewidzianych procedur specjalnych: wybór większością (tylko) absolutną lub zastosowanie balotażu między dwoma kandydatami, także z wymaganą tylko absolutną większością ${ }^{58}$.

Rozwiązanie przyjęte przez Jana Pawła II istotnie stanowiło wielkie novum, bowiem oznaczało zerwanie z trwającą ponad osiem wieków niewzruszoną tradycją większości kwalifikowanej w dyscyplinie wyboru papieża. $\mathrm{Z}$ jednej strony ułatwiało to wprawdzie zakończenie przedłużającego się konklawe, gdyby stosunkowo wysoko ustalona większość kwalifikowana okazała się niemożliwa do osiągnięcia - z drugiej zaś strony stwarzało możliwość, iż ktoś może zostać wybrany nawet wbrew opozycji prawie połowy kardynałów, co wcześniej było niemożliwe w sytuacji, gdy zaledwie jeden głos sprzeciwu wykluczał zastosowanie procedury specjalnej.

55 Zob. G. May, Das Papstwahlrecht..., dz. cyt., s. 247.

${ }^{6}$ Konklawe, na którym wybrano Jana Pawła I, było jednym z najkrótszych w historii tej instytucji i trwało zaledwie 24 godziny (3 głosowania). Podobnie i następne konklawe nie były o wiele dłuższe: Jan Paweł II został wybrany po dwóch dniach w ósmym głosowaniu, a Benedykt XVI w czwartym głosowaniu, drugiego dnia konklawe. Zob. P. V. Aimone, Le modalità procedurali..., dz. cyt., s. 618-619.

57 Czyli po 30 lub 33 głosowaniach, w zależności od tego, czy pierwsze z nich odbyło się już pierwszego dnia konklawe po południu. Zgodnie z przepisami UDG 63 i 72, jeśli konklawe rozpoczyna się przed południem, w pierwszym dniu ma miejsce tylko jedno głosowanie, a w kolejnych po cztery (dwa przed, a dwa po południu). Jeśli konklawe rozpoczyna się w godzinach popołudniowych, w pierwszym dniu nie przeprowadza się głosowania. Harmonogram kolejnych dni konklawe prezentuje W. Jakubowski, Podstawowe akty ustrojowe Państwa Miasta Watykańskiego, Pułtusk - Warszawa 2004, s. 91-97. Niektórzy nie traktują jednak pierwszego dnia konklawe jako dnia głosowań i stosują inne wyliczenia, podając, iż przejście do procedury nadzwyczajnej może mieć miejsce po 34 głosowaniach. Zob. W. Jakubowski, O Roma felix..., dz. cyt., s. 312-314.

$5^{8}$ Zob. UDG 75. 
Komentatorzy nowej ustawy o wyborze papieża nie tylko dostrzegali tę ważną zmianę, ale podkreślali, iż jest to decyzja bardzo nowatorska i to właśnie w niej tkwi fundamentalne znaczenie znowelizowanej regulacji. Niektórzy dopatrywali się jednak w tym rozwiązaniu poważnych niebezpieczeństw i zwracali uwagę, iż pojawienie się kandydata cieszącego się wsparciem więcej niż połowy elektorów, nieosiągającego jednak większości kwalifikowanej, może doprowadzić do całej serii „bezproduktywnych” głosowań, uskutecznianych świadomie, wbrew znaczącej mniejszości, jedynie w oczekiwaniu na wyczerpanie ustalonej liczby głosowań i doprowadzić do nadzwyczajnej formy wyboru z zastosowaniem większości absolutnej59. Zagrożenia dopatrywano się nie tylko w tym, że konklawe może obrócić się w zwykłą, czysto świecką grę wyborczą z rozmaitymi jej technikami, ale także w tym, iż dokonanie wyboru papieża tak obniżoną większością głosów może odbić się negatywnie na sposobie sprawowania władzy przez Biskupa Rzymu, który w pełnieniu funkcji następcy św. Piotra musiałby się zmierzyć ze stosunkowo liczną opozycją w Kościele.

W tej sytuacji Benedykt XVI zdecydował się na znowelizowanie nr. 75 konstytucji apostolskiej Universi Dominici gregis i przywrócenie wymogu większości dwóch trzecich głosów, także w sytuacji, w której wybór będzie dokonany na drodze balotażu, czyli między dwoma tylko kandydatami. Dokonało się to na mocy na mocy motu proprio Benedykta XVI Constitutione apostolica promulgowanego 11 czerwca 2007 roku $^{60}$. W samej ustawie zostały przedstawione racje skłaniające papieża do takiego kroku: były nimi wysuwane przez osoby cieszące się autorytetem postulaty, kierowane jeszcze do Jana Pawła $\mathrm{II}^{61}$, aby powrócić do uświęconej tradycją większości dwóch trzecich głosów. W opinii komentatorów decyzja Benedykta XVI o przywróceniu dawnej dyscypliny była zasadna i słuszna, jako że pozwala ona zaradzić nasuwającym się wątpliwościom, zapobiega podejrzeniom o naganne stosowanie machinacji elektoralnych, a nawet eliminuje ewentualne próby podważania ważności

59 Zob. G. May, Mehrheitsverhältnisse bei Papstwahlen, [w:] Iudicare inter fideles. Festschrift für Karl-Theodor Geringer zum 65. Geburtstag, St. Ottilien 2002, s. 280-285; P. V. Aimone, Le modalità procedurali..., dz. cyt., s. 577.

6o Zob. AAS, 2007, vol. 99, s. 776-777.

6r Z takim apelem miała się zwrócić do Jana Pawła II grupa niemieckojęzycznych kardynałów podczas konsystorza w 2001 roku. Zob. J. L. Allen, Konklawe. Strategie, uczestnicy i przebieg wyborów następnego papieża, Warszawa 2004, s. 140. 
wyboru papieża ${ }^{62}$. Nawet jeśli powrót do większości kwalifikowanej może być postrzegany jako negatywny dla efektywności wyboru, to jednak należy pamiętać o tym, iż większość w konklawe nie może być postrzegana jedynie w kategoriach przewagi liczbowej, ale swego rodzaju impulsu pobudzającego do eklezjalnego rozeznania i osiągnięcia jedności ${ }^{63}$. Instytucja większości kwalifikowanej sprzyja dokonaniu wyboru kandydata prawdziwie godnego, wokół którego skupi się znacząca grupa elektorów, a w tym sensie przyczynia się do budowania jedności Kościoła oraz zaufania względem następcy św. Piotra.

\section{Duchowy wymiar konklawe wyrazem jedności Kościoła}

Powyższe uwagi na temat większości głosów, rozmaitych narzędzi techniczno-prawnych należących do procedury i niebezpieczeństwa sprowadzenia wyboru Biskupa Rzymu do zwykłej gry wyborczej nie mogą jednak przysłaniać tego, że elekcja następcy św. Piotra nie jest aktem o charakterze politycznym, ale wybitnie religijnym. Ten duchowy aspekt konklawe nie może być pomijany, gdyż także on - a może nawet przede wszystkim on - sprawia, że zadanie kardynałów elektorów winno być postrzegane w kategoriach posługi pełnionej przez nich dla dobra Kościoła. W tym świetle należy także patrzeć na samą instytucję konklawe i regulację elekcji papieża - nie chodzi w nich wyłącznie o użyteczność służącą uporządkowanemu, sprawnemu i prawidłowemu przebiegowi samego wyboru, ale zagwarantowanie, iż wybór ten dokona się w atmosferze religijnego skupienia, a kardynałowie elektorzy jako zasadę i cel swego działania będą sobie stawiali „jedynie chwałę Boga i dobro Kościoła" ${ }^{4}$.

Wiele norm konstytucji apostolskiej Universi Dominici gregis, a przede wszystkim Obrzędy konklawe zatwierdzone przez Jana Pawła II 5 lutego 1998

${ }_{62}$ Zob. J. Miñambres, Nuove determinazioni sulle capacità decisionali del collegio dei Cardinali riunito in conclave, „Ius Ecclesiae”, R. 19, 2007, s. 758-762; P. V. Aimone, Ripristino assoluto della maggioranza qualificata nell'elezione del Romano Pontefice, „Apollinaris”, R. 80, 2007, s. 857-862; J. Ammer, Das Motu Proprio Papst Benedikts XVI. zur Änderung des Papstwahlgesetzes „Universi Dominici gregis”, „Folia Teologica”, R. 18, 2007, s. 5-16; L. Örsy, Una scelta per l'unità. Le ragioni di un ritorno alla tradizione per l'elezione del papa, „Il Regno. Attualità”, 2007, nr 14, s. 441-442.

63 Zob. M. Mosconi, L'elezione..., dz. cyt., s. 245.

64 UDG 83. 
roku ${ }^{65}$, przewiduje liczne celebracje liturgiczne i akty o charakterze ascetycznym, które akcentują, iż wybór następcy św. Piotra łączy się z żarliwą modlitwą do Ducha Świętego zarówno członków Kolegium Kardynalskiego, jak i całej wspólnoty Kościoła.

Mimo iż w konstytucji wydanej przez Jana Pawła II sama instytucja konklawe została zreformowana i dostosowana do potrzeb zmieniających się czasów - przede wszystkim zniknął element fizycznego zgromadzenia i zamknięcia kardynałów elektorów w jednym miejscu - przymiot „świętego” odosobnienia przywołany w definicji konklawe zawartej w konstytucji apostolskiej Pawła VI Romano Pontifici eligendo nie traci na aktualności ${ }^{66}$. Jan Paweł II wskazał, iż sam akt wyboru papieża ma się dokonywać w kaplicy Sykstyńskiej ${ }^{67}$, „gdzie wszystko sprzyja uświadomieniu sobie obecności Boga, przed którego obliczem pewnego dnia każdy będzie musiał stanąć na sąd”, uzasadniając to sakralnym charakterem wyboru i potrzebą, „aby mógł on przebiegać w odpowiednim miejscu, gdzie, z jednej strony, czynności liturgiczne dobrze łączyłyby się z formalnościami prawnymi, a z drugiej strony, elektorzy mogliby lepiej przygotować się duchowo na przyjęcie wewnętrznych poruszeń Ducha Świętego".

Nie sam fakt fizycznego odcięcia elektorów od świata jest ważny - choć oczywiście ma ono sprzyjać dochowaniu tajemnicy i chronić wolności wyboru - ale to, że Kościół, pozostawiając na zewnątrz sprawy tego świata, poprzez wybranych następców apostołów powołanych do grona kardynałów wsłuchuje się uważnie w głos Ducha Świętego ${ }^{68}$.

Pośród licznych duchowych aspektów konklawe, które mają wyrazić i przyczynić się do tego, by wybór papieża rzeczywiście dokonywał się ze świadomością działania z Bożej inspiracji i w Jego obecności, wymienić należy: Mszę św. Pro eligendo Papa odprawianą w dniu rozpoczęcia konklawe ${ }^{69}$, hymn

65 Zob. Officium de Liturgicis Celebrationibus Summi Pontificis, Ordo Rituum Conclavis, [dalej: ORC], E Civitate Vaticana 2000.

66 RPE 42: „Konklawe jest rozumiane w ten sposób, że obejmuje pewne określone miejsca, jakby święte odosobnienie, w którym po wezwaniu światła Ducha Świętego, kardynałowie elektorzy dokonują wyboru Ojca Świętego i w którym [...] zamieszkują dzień i noc aż do czasu dokonania wyboru, nie utrzymując żadnego kontaktu z pozostającymi na zewnątrz osobami i rzeczami [...]”.

${ }_{7}$ Zob. UDG, wstęp. W poprzedniej konstytucji mowa była jedynie o „kaplicy”.

68 Zob. M. Mosconi, L'elezione..., dz. cyt., s. 241-242.

69 Zob. UDG 49; ORC 18-28. 


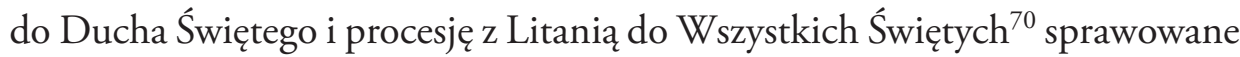
w tym samym dniu, rozważania ascetyczne i medytacje wygłaszane w trakcie trwania konklawe ${ }^{71}$, religijne formuły przysięgi składanej przez kardynałów i inne osoby uczestniczące w konklawe, podkreślające świadomość obecności Boga w czynnościach wyboru papieża ${ }^{72}$, modlitwy i inne akty liturgiczne przewidziane w różnych momentach konklawe (koncelebrowana Eucharystia według formularzy specjalnie przewidzianych na ten czas $^{73}$, wspólne sprawowanie niektórych części liturgii godzin ${ }^{74}$, a także modlitwy odmawiane podczas głosowań ${ }^{75}$, spośród których przywołać trzeba odmawianą przez wszystkich razem modlitwę do Ducha Świętego Adsumus ${ }^{76}$, w której elektorzy, świadomi własnych słabości proszą, by Pocieszyciel kierował ich decyzjami i wskazał Kościołowi właściwą drogę, nie dopuszczając do tego, by wyborcy kierowali się czysto ludzkimi upodobaniami, sympatiami osobistymi czy względem na pełnione funkcje).

W konstytucji o wyborze Biskupa Rzymskiego zachęca się ponadto, by cały Kościół trwał jednomyślnie na modlitwie, w łączności z kardynałami elektorami, prosząc Wszechmogącego Boga o pomoc i światło Ducha Świętego konieczne dla wyborców, by Pan „oświecił umysły elektorów i zjednoczył ich w tym zadaniu, ażeby nastąpił szybki, jednomyślny i owocny wybór, czego wymaga zbawienie dusz i dobro całego Ludu Bożego"77. O przewodzenie takim modlitwom, zwłaszcza w rzymskich bazylikach patriarchalnych, są przede wszystkim proszeni ci kardynałowie, którzy ukończyli osiemdziesiąt lat i nie biorą już udziału w głosowaniach ${ }^{78}$.

Wspólna modlitwa ma sprawić, by wybór nowego papieża, był „w pewnym sensie działaniem całego Kościoła, a nie dotyczącym jedynie kolegium

70 Zob. UDG 50; ORC 29-38.

${ }_{71}$ Zob. UDG 13/d, 52, 74.

${ }_{72}$ Zob. UDG 12, 48, 53, 66.

73 Zob. ORC 79-82. Obrzędy konklawe zawierają teksty Mszy św. wotywnych o Duchu Świętym, za Kościół, o Najświętszej Maryi Pannie w Wieczerniku i o Świętych Apostołach Piotrze i Pawle.

74 Zob. ORC 12-15.

75 Zob. ORC 96-107.

$7^{6}$ Zob. ORC 102.

77 UDG 84.

$7^{8}$ Zob. UDG 85. 
elektorów"79. W ten sposób, dzięki duchowym więzom łączącym kardynałów elektorów ze wspólnotą trwającą na modlitwie na całym świecie, klauzura konklawe nie odgradza kardynałów wyborców od pozostałych wiernych i nie stanowi przeszkody, by wybór Biskupa Rzymu był aktem komunii i wyrazem jedności całego Kościoła ${ }^{80}$.

\section{The Election of Roman Pontiff in Perspective of the Unity of the Church}

Summary

This article includes a deepened presentation and a commentary on some elements of the procedure of the election of the Pope, which underline the unity of the believers' community. It is a unity in the sense of a participation of the whole Church in the election process, and secondly in that a special strengthening of the Pope to fulfill the ministry of unity of the Christ's Church is accomplished by his election. The elements in question are as follows: entrusting of the election of the Bishop of the Church of Rome to the Cardinals of the Holy Roman Church, a majority of votes necessary for a valid election of the bishop of Rome, and a spiritual dimension of a conclave, as well as a calling directed to all the Faithful to participate in this special act.

Keywords: bishop, election, unity, Church, pope

79 UDG 84.

8o Zob. M. Mosconi, L'elezione..., dz. cyt., s. 242. 